\title{
KANDUNGAN ENERGI METABOLIS SEMU PAKAN DAN ENERGI METABOLIS SEMU TERKOREKSI N PADA GANDUM DENGAN SUPLEMENTASI ENZIM SEBAGAI SUBSTITUSI JAGUNG
}

\author{
Metabolizable Energy Feed Content and Metabolizable Energy Corrected $N$ in Wheat with Enzyme \\ Supplementation as Substitution of Corn
}

\author{
Sandha Octavia P., Irfan H. Djunaidi dan Eko Widodo \\ Faculty of Animal Husbandry, Brawijaya University \\ Veteran, Malang, East Java Province \\ e-mail : sandha.octavia@gmail.com
}

\begin{abstract}
Feed broiler is one important factor that is very supportive of other factors when broiler maintenance. One way to reduce the use of maize is to use alternative raw materials of wheat. Wheat can be obtained and the price is cheaper than corn but contains a high Non Starch Polysaccharide, while the poultry digestive tool is not able to digest such crude fiber because it has no crude fiber-breaking enzymes so it needs enzyme addition to the efficient use of nutrient feed. The research method used is the experimental method using Completely Randomized Design consisting of 4 treatments 5 replications. The treatment is as follows $P_{0}$ (without wheat and xylanase); $P_{1}$ (substitution of maize with 20\% wheat); $P_{2}$ (maize substitution with $40 \%$ wheat) and $P_{3}$ (substitution of maize with $60 \%$ wheat). The observed variables are metabolic energy of pseudo-feed and metabolically correlated false energy $n$. Data were analyzed by analysis of variance (ANOVA) if there are differences among the treatments followed by Duncan's Test. The results showed that the use of wheat with a xylanase enzyme supplementation as a substitute corn provides highly significant effect $(P<0.01)$ on the apparent metabolize energy of feed and apparent metabolize energy corrected $N$. The addition of xylanase enzymes in feed with the substitution of wheat by 20 percent produce the best feed metabolizable energy among other treatments.
\end{abstract}

Keywords : Broiler, Wheat, Enzymes, Energy, Feed

\section{PENDAHULUAN}

Pakan broiler merupakan salah satu faktor penting yang sangat menunjang faktor lain saat pemeliharaan broiler. Pakan yang berkualitas akan menunjang kualitas genetik yang dimiliki oleh broiler sehingga akan memacu pertumbuhan broiler. Pakan broiler sebagian besar disokong oleh sumber nabati. Sumber nabati yang dimaksud adalah bahan baku yang berasal dari tanaman yang sebagian besar biji-bijian seperti jagung yang digunakan hingga lebih dari 50\% dalam pakan. Jagung merupakan komponen terbesar yang digunakan dalam pembuatan pakan broiler dan juga sebagai sumber energi utama dalam pakan. Produksi jagung di Indonesia saat ini belum dapat memenuhi kebutuhan pakan broiler di Indonesia. Kebutuhan jagung untuk pakan di Indonesia pada tahun 2014 mencapai 14,7 juta ton (Antara, 2014) sehingga kebutuhan jagung untuk pakan dan pangan mengalami persaingan di sisi kebutuhan dan juga luas lahan penanaman komoditi jagung pangan dan pakan.
Kurangnya produksi jagung Indonesia untuk memenuhi kebutuhan pabrik pakan broiler ini mengakibatkan impor jagung secara besar masuk ke Indonesia untuk memenuhi kebutuhan.

Salah satu cara untuk mengurangi pemakaian jagung ialah dengan menggunakan bahan baku alternatif. Salah satu bahan baku alternatif yang dapat digunakan adalah gandum. Gandum dapat diperoleh dan harganya lebih murah dari jagung. Permasalahannya adalah bahan pakan tersebut mengandung Non Starch Polysaccahride tinggi, sementara alat pencernaan broiler tidak mampu mencerna serat kasar tersebut karena tidak memiliki enzim pemecah serat kasar. Hal ini menyebabkan performa broiler tidak optimal bila gandum digunakan dalam jumlah tinggi. Salah satu imbuhan pakan yang saat ini mulai banyak diteliti dan digunakan di negara maju adalah enzim. Penambahan enzim diharapkan dapat membantu broiler untuk mencerna bahan pakan yang sulit dicerna sehingga meningkatkan ketersediaan zat gizi bahan tersebut. Beberapa 
peneliti telah melaporkan bahwa penambahan xilanase ke dalam pakan dengan bahan dasar gandum dan barley dapat menurunkan kekentalan dari digesta di dalam saluran pencernaan (Silva dan Smithard, 1997).

Angelicova et al. (2005) menyatakan bahwa pemberian enzim (xilanase dan protease) cenderung meningkatkan PBB dan menurunkan konversi pakan. Selain memberikan dampak terhadap penampilan produksi, pemberian enzim dalam pakan adalah untuk mengurangi aliran nutrisi yang tidak tercerna yang dapat digunakan untuk fermentasi populasi mikroba merugikan dalam saluran pencernaan bagian bawah. Peningkatan kecernaan nutrisi pada pakan yang disubtitusi dengan gandum penting untuk dilakukan karena dengan penggunaan gandum ini diharapkan performa yang dihasilkan mendekati atau sama dengan performa yang dihasilkan dengan pakan yang berbasis pada jagung, sehingga ketergantungan pada jagung dapat dikurangi terutama pada masa-masa sulit memperoleh jagung.

\section{MATERI DAN METODE}

Penelitian dilaksanakan di kandang ayam broiler Kecamatan Tumpang, Kabupaten Malang pada Januari 2017. Bahan yang digunakan adalah bahan baku penyusunan pakan, dan ayam broiler strain Cobb jantan umur 40 hari. Persiapan bahan baku dimulai dengan analisa proksimat, kandungan NSP dan kerapatan jenis bahan baku dan pakan pada setiap perlakuan. Bahan baku yang telah dianalisa digunakan untuk menyusun pakan dengan substitusi jagung dengan gandum dengan berbagai persentase $(0 ; 20 ; 40$ dan $60 \%$ ). Pakan yang telah disubtitusi jagung di tambahkan dengan enzim xylanase dengan tingkat yang sama yaitu 11.000 Unit/ kg pakan.

Metode penelitian adalah metode eksperimen dengan menggunakan Rancangan Acak Lengkap yang terdiri atas 4 perlakuan 5 ulangan. Adapun perlakuan adalah sebagai berikut $\mathrm{P}_{0}$ (tanpa gandum dan xilanase); $\mathrm{P}_{1}$ (subtitusi jagung dengan $20 \%$ gandum); $\mathrm{P}_{2}$ (subtitusi jagung dengan $40 \%$ gandum) dan $\mathrm{P}_{3}$ (subtitusi jagung dengan $60 \%$ gandum). Variabel yang diamati adalah energi metabolis semu pakan dan energi metabolis semu terkoreksi $\mathrm{N}$.

\section{Pengambilan Sampel dan Pengukuran Gross Energy \\ Pengambilan sampel dilakukan setelah} broiler diberi pembiasaan terhadap pakan uji coba selama 7 hari. Koleksi eksreta dilakukan selama 4 hari. Eksreta yang di peroleh di masukkan kedalam suhu $-20^{\circ} \mathrm{C}$ untuk analisis selanjutnya. Sampel akan di thawing dan di homogenkan untuk dikeringkan dan dilakukan analisis kimia. Sampel dikeringkan dengan Oven Drying. Eksreta yang sudah dikeringkan akan melalui saringan berukuran $1 \mathrm{~mm}$ untuk persiapan analisis kimia.

Pengukuran gross energy menggunakan bom calorimeter dan reagen sodium karbonat standar dan indicator methyl orange. Pengukuran gross energy sesuai dengan standar prosedur yang dilakukan laboratorium.

\section{Perhitungan dan Analisis data}

Perhitungan konsumsi gross energy, Retensi N, gross energy pada eksreta, energi metabolis semu, dan energi metabolis terkoreksi $\mathrm{N}$ dihitung dengan rumus berikut :

Konsumsi gross energy = konsumsi pakan (bahan kering) x gross energy pada pakan

Retensi $\mathrm{n}=\mathrm{n}$ pakan $-\mathrm{n}$ eksreta

Gross energy pada eksreta = gross energy eksreta $\mathrm{x}$ jumlah eksreta (bahan kering)

Data dianalisis dengan analisis ragam (analysis of variance/ANOVA) jika ada perbedaan antar perlakuan dilanjutkan dengan Uji Duncan's (Steel and Torie, 2003).

$$
\begin{aligned}
& \text { Energi metabolisme semu (AME) (kkal) }=\frac{\text { gross energy pakan - gross energy ekskreta }}{\text { konsumsi pakan }} \\
& \begin{aligned}
\text { Energi metabolisme semu terkoreksi } \mathrm{n}(\text { AMEN) (kkal) } \\
\qquad=\frac{\text { gross energy pakan }- \text { gross energy ekskreta }}{\text { konsumsi pakan }}-8,73 \mathrm{XNN}
\end{aligned}
\end{aligned}
$$




\section{HASIL DAN PEMBAHASAN}

Hasil pengkuran kerapatan jenis jagung, gandum, dan juga setiap jenis perlakuan pakan dapat dilihat pada Tabel 1 .

Tabel 1. Kerapatan Jenis Jagung, Gandum dan Setiap Perlakuan Pakan

\begin{tabular}{cc}
\hline Perlakuan & Kerapatan Jenis $(\mathbf{g} / \mathbf{m l})$ \\
\hline Gandum & 0,69 \\
Jagung & 0,80 \\
Pakan $\mathrm{P}_{0}$ & 0,73 \\
Pakan $\mathrm{P}_{1}$ & 0,72 \\
Pakan $\mathrm{P}_{2}$ & 0,71 \\
Pakan $\mathrm{P}_{3}$ & 0,70 \\
\hline
\end{tabular}

Berdasarkan Tabel 1 dapat dilihat bahwa kerapatan jenis gandum lebih rendah dibandingkan kerapatan jenis jagung, jagung lebih tinggi $0,11 \mathrm{~g} / \mathrm{ml}$ daripada gandum. Setiap perlakuan pakan diatas diberi subtitusi gandum terhadap jagung kecuali pada $\mathrm{P}_{0}(100 \%$ jagung); pakan $\mathrm{P}_{1}$ mengandung $20 \%$ gandum; $\mathrm{P}_{2}$ mengandung $40 \%$ gandum dan $\mathrm{P}_{3}$ mengandung $60 \%$ gandum. Penambahan gandum yang meningkat mengakibatkan penurunan kerapatan jenis pada pakan $\mathrm{P}_{1}, \mathrm{P}_{2}$ dan $\mathrm{P}_{3}$ sebanyak 0.01 $\mathrm{g} / \mathrm{ml}$. Berdasarkan data dari tabel diatas maka dapat disimpulkan bahwa semakin banyak gandum yang disubtitusikan terhadap jagung ke dalam pakan maka akan semakin rendah kerapatan jenis dari pakan tersebut. Rendahnya kerapatan jenis akan berpengaruh kepada kerapatan nutrien di dalam pakan, nutrien yang terkandung di dalam volume yang sama akan lebih sedikit pada pakan yang memiliki kerapatan jenis yang rendah.

Hasil analisis ragam menunjukkan bahwa penggunaan gandum dengan suplementasi xilanase sebagai subtitusi jagung memberikan pengaruh sangat nyata $(\mathrm{P}<0,01)$ terhadap energi metabolis semu pakan dan energi metabolis semu terkoreksi N. Rata-rata energi metabolis semu disajikan pada Tabel 2.

Berdasarkan Tabel 2 dapat dilihat bahwa energi metabolis terbaik diperoleh dari perlakuan $\mathrm{P}_{0} . \mathrm{P}_{0}$ merupakan pakan yang berbasis jagung, dan memiliki kecernaan yang lebih baik dibandingkan gandum, hal ini dapat disebabkan kandungan pati jagung lebih banyak dari pada gandum sedangkan kandungan NSP jagung lebih rendah dibandingkan gandum. Kandungan pati jagung 65,2\% sedangkan gandum hanya $59,5 \%$ sementara itu kandungan NSP jagung sebesar 8,7\% sedangkan gandum sebesar 10,9\% (Peron dan Amerah, 2012). Hasil penelitian ini sesuai dengan yang dilaporkan Friesen et al.
(1992) bahwa penambahan enzim dalam pakan broiler yang terdiri dari gandum, barley, oat dan rye dapat meningkatkan secara nyata $(\mathrm{P}<0.01)$ AMEN (Apparent Metabolize Energy), juga dapat memperbaiki bobot badan dan konversi pakan broiler. Wu et al (2004) juga melaporkan bahwa kombinasi enzim phytase dan xylanase maupun secara individu dapat meningkatkan energi metabolis pada pakan broiler yang mengandung gandum.

Tabel 2. Pengaruh penggunaan gandumdengan suplementasi enzim xilanase sebagai subtitusi jagung terhadap energi metabolis semu dan energi metabolis semu terkoreksi $\mathrm{N}$

\begin{tabular}{ccc}
\hline Perlakuan & $\begin{array}{c}\text { Energi } \\
\text { Metabolis } \\
\text { Semu (Kkal) }\end{array}$ & $\begin{array}{c}\text { AMEn }_{\mathbf{n}} \\
\text { (Kkal) }\end{array}$ \\
\hline $\mathrm{P}_{0}$ & $3.090 \pm 2,15^{\mathrm{d}}$ & $3.071 \pm 2,26^{\mathrm{d}}$ \\
$\mathrm{P}_{1}$ & $3.073 \pm 3,49^{\mathrm{c}}$ & $3.053 \pm 3,25^{\mathrm{c}}$ \\
$\mathrm{P}_{2}$ & $3.050 \pm 5,22^{\mathrm{b}}$ & $3.035 \pm 4,50^{\mathrm{b}}$ \\
$\mathrm{P}_{3}$ & $3.034 \pm 4,22^{\mathrm{a}}$ & $3.020 \pm 2,82^{\mathrm{a}}$ \\
\hline
\end{tabular}

Keterangan: Notasi yang berbeda menunjukkan perbedaan yang sangat nyata $(\mathrm{P}<0,01)$ antar perlakuan

Gandum memiliki kandungan NSP yang dapat menghambat broiler untuk mencerna nutrisi yang masuk ke dalam organ pencernaan dengan menambahkan viskositas digesta dan menambah passage rate dari sistem pencernaan broiler. Tingginya kandungan NSP menyebabkan energi yang dapat dicerna di dalam saluran pencernaan menjadi berkurang, hal ini dicerminkan dari menurunnya energi metabolis pada $\mathrm{P}_{1}, \mathrm{P}_{2}$, dan $\mathrm{P}_{3}$. NSP menyebabkan peningkatan viskositas digesta pada usus sehingga dapat menurunkan penyerapan nutrien. AME memiliki korelasi negatif dengan kandungan NSP yang larut dalam air (Annison dan Choct, 1991). Hal ini berarti semakin tinggi kandungan NSP yang larut dalam air semakin rendah AME yang diperoleh oleh broiler. Penggunaan xilanase pada pakan yang mengandung gandum dapat meningkatkan nilai AME yang dihasilkan (Annison, 1992). Pada penelitian tersebut disimpulkan bahwa rendahnya nilai AME yang dihasilkan berkaitan dengan NSP yang terkandung. NSP yang tinggi akan mengakibatkan broiler sulit dalam mencerna nutrisi yang masuk kedalam saluran pencernaan yang secara otomatis juga mempengaruhi nilai AMEN. 
Hasil ini hampir sama dengan penelitian Kiarie, Romero, dan Ravindran (2014) yang melaporkan nilai AMEN pakan yang berbasis gandum yang disuplementasi xilanase memiliki AMEN sebesar 3057 kkal sedangkan pakan yang tidak disuplementasi xilanase hanya memperoleh AMEN sebesar 2985 kkal. Peningkatan tersebut dapat diakibatkan enzim xilanase yang ditambahkan pada pakan dapat merombak NSP yang terdapat dalam gandum sehingga dapat meningkatkan metabolisme energi di dalam organ pencernaan broiler. Adanya perbedaan nilai AMEN dan AME disebabkan oleh nilai AMEN memperhitungkan adanya konversi energi sebagai faktor koreksi dari nitrogen sebesar asam urat yang jika dioksidasi secara sempurna menghasilkan 8.22 $\mathrm{kkal} / \mathrm{g}$. NSP yang tinggi akan mengakibatkan broiler sulit dalam mencerna nutrisi yang masuk kedalam saluran pencernaan yang secara otomatis juga mempengaruhi nilai AMEN. Gandum memiliki kandungan NSP yang dapat menghambat broiler untuk mencerna nutrisi yang masuk ke dalam organ pencernaan dengan menambahkan viskositas digesta dan menambah passage rate dari sistem pencernaan broiler.

\section{SIMPULAN}

Penggunaan gandum dengan suplementasi xilanase sebagai subtitusi jagung memberikan pengaruh sangat nyata $(\mathrm{P}<0,01)$ terhadap energi metabolis semu pakan dan energi metabolis semu terkoreksi N. Penambahan xilanase pada pakan dengan subtitusi gandum sebanyak 20 persen menghasilkan energi metabolis pakan terbaik diantara perlakuan lainnya.

\section{DAFTAR PUSTAKA}

Angelovicova, M., Mendel, J., Angelovic, M., and Kacaniova, M., 2005. Effect of Enzyme Addition to Wheat Based Diets in Broilers. Trakya Univ J. Sci, 6(1) :2933.

Annison, G. 1991. Relationship Between The Levels of Soluble Non Starch Polysaccharides and Apparent Metabolizable Energy of Wheats Assayed in Broiler Chickens. J. Agric. Food Chem. 39 : 1252-1256.

Annison, G. and M. Choct. 1991. Anti-nutritive activities of cereal non-starch polysaccharides in broiler diets and strategies minimizing their effects. World's Poult. Sci. J. 47 : 232-242.
Antara. 2014. Kebutuhan Jagung Indonesia Mencapai 14,7 juta Ton. Jakarta. Diakses pada 8 November 2016.

Friesen, O.D., W.Guenter, R.R. Marquardt, and B.A. Rotter. 1992. The effect of enzyme supplementation on the apparent energy and nutrient digestibilities of wheat, barley, oats, and rye for the young broiler chick. Poult. Sci. 71:1710-1721

Kiarie. E., L.F. Romero., and V. Ravindran. 2014. Growth Performance, nutrient utilization, and digesta characteristic in broiler chickens fed corn or wheat diets without or with supplemental xylanase. Poultry Science. 93: 1186-1196

Peron, A and A. Amerah. 2012. Wheat as an Alternative to Corn. Asian Feed Technical.

Silva, S.S.P. and R.R. Smithard. 1997. Digestion of protein, fat and energy in rye based broiler diets is improved by addition of exogenous xylanase and protease. Br. Poult. Sci. 38: 538

Steel, R. G. D. dan J. H. Torrie. 2003. Prinsip dan Prosedur Statistik. Suatu Pendekatan Biometrik. Terjemahan : Ir. Bambang Soemantri. Edisi Kedua. PT Gramedia, Jakarta

Wu, Y.B., Ravindran, V., Thomas, D.G., Birtles, M.J., and Hendriks, W.H. 2004. Influence of phytase and xylanase, individually or in combination, on performance, apparent metabolisable energy, digestive tract measurements and gut morphology in broilers fed wheatbased diets containing adequate level of phosphorus. Br Poult Sci 45:76-84. 